$$
\text { article }
$$

\section{The impact of conditionality on the welfare rights of EU migrants in the UK}

\author{
Peter James Dwyer, peter.dwyer@york.ac.uk \\ University of York, UK \\ Lisa Scullion, l.scullion@salford.ac.uk \\ University of Salford, UK \\ Katy Jones, k.e.jones@salford.ac.uk \\ University of Salford, UK \\ Alasdair Stewart, Alasdair.stewart@glasgow.ac.uk \\ University of Glasgow, UK
}

This paper highlights and explores how conditionality operating at three levels (the EU supranational level, the UK national level and in migrants' mundane 'street level' encounters with social security administrators), come together to restrict and have a negative impact on the social rights of EU migrants living in the UK. Presenting analysis of new data generated in repeat qualitative interviews with $49 \mathrm{EU}$ migrants resident in the UK, the paper makes an original contribution to understanding how the conditionality inherent in macro level EU and UK policy has seriously detrimental effects on the everyday lives of individual EU migrants.

key words social citizenship $\cdot$ EU migration $\cdot$ welfare benefits $\cdot$ social integration

\section{Introduction}

Following enlargement of the European Union (EU) in 2004 and 2007 over one million Central and Eastern European (CEE) migrants from Accession $8^{1}$ (A8) and Accession 2 (A2) ${ }^{2}$ countries entered the UK. The UK government's decision not to impose restrictions on the entry of A8 workers (see Currie, 2008), a long period of sustained economic growth, a favourable disparity in wage earning potential between many CEE nations and the UK, alongside a comparatively low and regressive tax system combined to make made the UK an attractive proposition for new EU citizens looking to exercise their rights to freedom of movement (Stenning et al, 2006). While some have relocated elsewhere (Pollard et al, 2008), substantial numbers 
remain and the UK continues to be a popular destination country for EU migrants (Bruzelius et al, 2016). Since 2011, the number of European Economic Area (EEA) ${ }^{3}$ nationals living in the UK has increased by nearly 700,000 to total 3.3 million people. Approximately half entered from Poland and Romania with a further 24 per cent entering from Italy, Portugal and Spain; their movement most likely triggered by a search for employment given high levels of unemployment in Southern Europe (Migration Observatory, 2016). Initially the New Labour government welcomed EU migrants as hard-working contributors to the UK economy and welfare state (Blair, 2004). However, as unexpected numbers migrated to the UK, certain policymakers and members of the public from across the political spectrum started to view their presence as increasingly problematic (Mulvey, 2011; Cook et al, 2012). Arguably, in grappling with the trade-off between the closed solidarity implied in national welfare states and the diversity that international migration encourages, some on the Left have become highly 'circumspect when it comes to permissive migration regimes in general and the reality of freedom of movement in the EU in particular' (Parker, 2017, 480) The onset of the global financial crisis, increasing unemployment and growing populist fears about EU migrants' access to 'British' jobs and social welfare benefits (forcefully articulated by the right-wing Eurosceptic UKIP Party) (Farage, 2014), saw the UK government's stance on EU migration change. Under the Conservative/ Liberal Coalition (2010-2015) and the subsequent UK Conservative administration, the social rights of EU migrants in the UK became subject to critical scrutiny and systematic reduction.

Against this backdrop this paper explores the significance of welfare conditionality, at supra-national (EU), nation state (UK) and at what Lipsky (1980) called the 'street' level of implementation, in rendering the social security rights of EU migrants in the UK vulnerable to reduction and removal. At the supra-national level, by making the rights and freedoms of mobile EU migrants who relocate to another Member State (MS) contingent on activity in the paid labour market (PLM) (that is, conditional on worker status), EU law not only denies rights to non-workers but also helps establish a stratified framework in which the rights of all mobile EU migrants are potentially rendered more precarious, including those who cease to work in their host state. At the level of national policymaking, increasing restrictions on the welfare rights of EU migrants combine with the application of extended and intensified behavioural welfare conditionality to negatively structure the everyday interactions of EU migrants with the Jobcentre Plus (JC+) and Work Programme (WP) staff who implement the sanctions and support that are central to the UK's progressively more conditional welfare state (Dwyer, 2016). To explore these issues the paper draws on new data generated in repeat, qualitative interviews conducted with 49 EU migrants resident in the UK.

Part two of the paper sets out the EU Treaty principles underpinning mobile EU citizens' rights to live, work and access welfare provisions in another MS and highlights some of the unresolved tensions at the heart of EU law, in respect of 'inactive' mobile citizens' access to basic welfare rights. These are tensions which recent UK governments (faced with growing domestic concerns about the impacts of EU migration and the 2016 referendum on EU membership) sought to resolve by introducing a series of restrictions on EU migrants' welfare rights. Following an initial consideration of conditionality and the importance of considering its operation at different levels of the policy process, these UK restrictions are set out in part three. 
Part four outlines the method and sample used to generate the new data that informs the paper. Discussions in part five focus on the detrimental outcomes triggered by the application of the more stringent residency rules and the 'genuine prospect of work test' (GPoWT) for EU migrants who apply for out of work benefits. In part six, EU migrants' everyday encounters with those who implement the sanctions and mandatory support, which are central to the increasingly conditional UK welfare state are considered.

\section{A conditional promise? EU citizenship, freedom of movement and the social rights of EU migrants}

The notion of EU citizenship is set out in the Consolidated version of the Treaty on the Functioning of the European Union (TFEU),

Citizenship of the Union is hereby established. Every person holding the nationality of a Member State shall be a citizen of the Union. Citizenship of the Union shall be additional to and not replace national citizenship. (Article 20)

Every citizen of the Union shall have the right to move and reside freely within the territory of the Member States, subject to the limitations and conditions laid down in the Treaties and by the measures adopted to give them effect. (Article 21) (OJ 2012/C 326/01)

First established in the Maastrict Treaty (1992), the EU citizenship rights conferred on MS nationals include: the right to move and reside freely in the EU, limited political rights when resident in another MS, the right to petition the European Parliament and rights to diplomatic protection under the authority of another MS. However, critics have noted the lack of an explicitly social element and significant limitations on the 'fundamental' right to free movement granted by EU citizenship status (Thym, 2015). Commentators have long noted that, in reality, EU citizenship is a highly stratified status built around an exclusive ideal of the citizen as a paid worker, which has led to the creation of inferior social rights for many mobile EU citizens outside the PLM. Although some previous judgements in EU case law have stated that part-time employment on minimal hours may be enough to confer 'worker' status, it is clear that EU migrant workers (and latterly dependant members of their families) enjoy superior rights of residence and welfare in comparison to economically inactive migrants (see, for example, Pollard and Ross, 1994; Weiler, 1998; Ackers and Dwyer, 2002; Currie, 2008). ${ }^{4}$

Elsewhere within the EU's legal framework, the Charter of Fundamental Rights of the European Union (CFREU) specifies a more expansive vision of social rights.

1. The Union recognises and respects the entitlement to social security benefits and social services providing protection in cases such as maternity, illness, industrial accidents, dependency or old age, and in the case of loss of employment, in accordance with the rules laid down by Union law and national laws and practices. 
2. Everyone residing and moving legally within the European Union is entitled to social security benefits and social advantages in accordance with Union law and national laws and practices.

3. In order to combat social exclusion and poverty, the Union recognises and respects the right to social and housing assistance so as to ensure a decent existence for all those who lack sufficient resources, in accordance with the rules laid down by Union law and national laws and practices. (Article 34, CFREU [OJ 2012/C 326/02])

Potentially Article 34 appears to offer 'inactive' EU migrants access to basic accommodation and social assistance rights when resident elsewhere in the EU. However, any rights to live and work in another MS, and any implied attendant rights to social welfare remain 'subject to the limitations and conditions' noted above. Such conditions are routinely set out in secondary EU legislative measures (that is, Regulations and Directives). Article 7 of Directive 2004/38/EC on free movement, which details the limitations on residence rights (beyond a broadly unconditional generic right to three months' residence specified in Article 6), is significant in seriously limiting economically inactive EU migrants' substantive rights to free movement, residency and the promise, for those without sufficient resources, of access to 'social and housing assistance', implied in Article 34 CFREU.

1 All Union citizens shall have the right of residence on the territory of another Member State for a period of longer than three months if they:

(a) are workers or self-employed persons in the host Member State; or

(b) have sufficient resources for themselves and their family members not to become a burden on the social assistance system of the host Member State during their period of residence and have comprehensive sickness insurance cover in the host Member State. (Article 7. Directive 2004/38/EC [OJ L 158/ 93])

Although EU law asserts that mobile, EU workers can enjoy available social rights on taking up residence in another MS and attain the same rights as nationals after completing five years of residency, the reality for jobseekers and other 'inactive' mobile EU citizens is less positive. Directive 2004/38/EC makes it clear that free moment is conditional on a measure of economic self-sufficiency, 'for those who do not qualify as workers, self-employed, jobseekers, temporary service recipients or family members' (Thym, 2015, 20). Under Directive 2004/38/EC every EU national moving to the UK, including those deemed to be economically inactive, have a right to reside for up to three months. However, beyond this, resident EU nationals can only access specified social assistance benefits ${ }^{5}$ provided they satisfy 'right to reside' rules which require people to be economically active and able to support themselves above the social assistance level (Bruzelius et al, 2016).

Issues related to EU migrants' rights to free movement and access to social assistance benefits in other MSs, reflect 'divergent theoretical visions on how to perceive EU citizenship and the limits of solidarity' (Thym, 2015, 5). A 'residence model' asserts that all mobile EU citizens, including economically inactive ones, should be able to access social assistance benefits within their host state on the basis of their common status as citizens of the Union. In contrast, what Thym refers to as an 'integration 
model' 'accentuates the value of social cohesion and requires newcomers to develop a certain degree of societal bonds before they can claim equal access to all social benefits' (Thym, 2015, 50). These two approaches reflect wider philosophical arguments about social citizenship and the extent to which an individual citizen's access to publicly provided welfare benefits and services should be contingent on prior contribution through paid work (or other socially valued activity), or alternatively granted more unconditionally on the basis of a shared citizenship status (Oldfield, 1990).

Such broader debates about the extent and substance of EU citizenship have routinely been defined and clarified in the European Court of Justice's (ECJ) rulings on specific cases. Previously ECJ case law was associated with the promotion of an inclusive definition of mobile 'worker' that advanced a more expansive status-based model of EU migrants' residence and social assistance rights (see, for example, Case C-85/96). However, recently, the Court has endorsed a more restrictive interpretation (see Case C-67/14; Case C-299/14) of the rights of EU migrant jobseekers and those lacking sufficient resources. Interestingly, the judgment in European Commission v United Kingdom of Great Britain and Northern Ireland (Case C-308/14) found that the UK government's use of the right to reside test to deny certain benefits to economically inactive EU migrants did not breach Regulation (EC) No 883/2004, which sets out common rules to protect EU citizens' social security rights when moving within the EU. Currently longstanding 'tensions and uncertainties' (Thym, 2015) about the rights of EU migrants are being resolved through a reaffirmation of the commodified rights of workers rather than citizens. While it is important to recognise that how EU law is transposed may vary, depending on the diverse settings and multi-levels in which it is operationalised (see, for example, Parker and López Catalán, 2014), it would appear that the rights of EU migrants outside the PLM are increasingly to be cast aside as highly conditional, economic mobility becomes the 'epicentre of moral value' (O’Brien, 2013b).

\section{Conditionality and the rights and responsibilities of migrants}

As the conditional promise of EU citizenship is 'hollowed out' MS are keen to reassert their authority in relation to EU migrants (O'Brien, 2016). Several MS (including Austria, Belgium, Germany, the Netherlands and the UK), ${ }^{6}$ have recently implemented policies that reiterate the significance of national citizenship rather than residence in restricting eligibility to social assistance benefits whereby 'economically inactive EU migrants and jobseekers enter at their own risk' (Heindlmaier and Blauberger, 2017, 2). As Baldi and Wallace Goodman (2015) note, in such circumstances the specific policy frameworks or 'membership conditionality structures' (MCS) generated in response to immigration in different national settings become significant. Dependent on the unique prevailing 'institutional frameworks, policy legacies, and political calculations' (Baldi and Wallace Goodman, 2015, 1153), a nation's MCS work to differentially enhance or diminish the rights of individual migrant's citizenship/residency status, access to social welfare and civic integration in a host state.

Elsewhere, when considering how conditionality might be defined and operationalised to enable a comparative consideration of welfare state regime change, Clasen and Clegg identify three 'levels', or types, of conditions operating within welfare states which govern an individual's access to social security: 
The first, or primary, condition for the receipt of social security is always membership of a defined category of support...Analytically secondary to conditions of category are conditions of circumstance or in more common social security parlance, eligibility and entitlement criteria... The third and final level of conditionality...pertains to what could be called conditions of 'conduct', with the policy levers being the tightening or loosening of behavioural requirements and constraints imposed upon different kinds of benefit recipients. $(2007,172-174)$

Shutes (2016) recently argued that conditionality at all three levels, that is: category (for example, being defined as a mobile EU 'worker'); circumstance (right to reside rules, minimum earning thresholds, the GPoWT) and conduct (mandatory behavioural conditions such as job search and Work Focused Interviews (WFI)/training requirements under threat of benefit sanction), have been significant in reducing the rights of EU migrants in the UK. However, the importance of conditionality at an additional fourth level, that of front-line implementation (see Lipsky, 1980) also needs to be acknowledged as a factor in limiting the social security rights of EU migrants in the UK (compare, Carmel and Cerami, 2011). Breidahl highlights a tendency toward 'welfare chauvinism' within Scandinavian welfare states whereby migrants' face reduced or restricted entitlements to support in comparison to citizens and notes that 'at some points harsher policies have been introduced and implemented more eagerly when the target group for activation reforms has been immigrants' (2012, 119). In the UK, stringent residency rules and additional requirements, such as the GPoWT, have become an integral element of the complex and highly conditional 'activationist-plus' (O'Brien, 2013a) social assistance system now established for EU migrants. At best, this promotes situations in which the rules governing migrants' rights are poorly understood and well-meaning, but perhaps ill-informed, front line benefit administrators inadvertently advise individuals that they are ineligible for support (Oliver, 2013). At worse, it may lead to some bureaucrats denying EU migrants social assistance benefits because of individual discriminatory or racist attitudes. The UK setting, in which intensified, personalised and extended behavioural conditionality operates as the default norm for all claimants, with additionally, institutionalised welfare chauvinism openly endorsed within EU migrant specific welfare policies, certainly creates the conditions in which such behaviour may be easier to hide. Keen to be seen as reasserting national sovereignty in matters of migration, recent UK governments have been willing to further test the elasticity of the principles that underpin the highly contingent rights implied by EU citizenship status. They have done this by instigating a series of further restrictions on the rights of mobile EU citizens to access social benefits while in the UK.

\section{Restricting welfare: UK policy developments and the diminishing entitlements of EU migrants}

Below the supra-national EU level, many states, including the UK, have long histories of using immigration legislation to curtail the rights of immigrants. In the UK the Immigration Act (1971) required all new migrants to support themselves as a condition of entry and effectively spawned the 'no recourse to public funds' rules that deny many Third Country nationals access to social assistance benefits 
and services. Additionally, the 'Habitual Residence Test' (1994) requires that many immigrants, and some returning British nationals, prove they have resided in the UK for 'an appreciable amount of time' to retain eligibility to social assistance benefits (Sibley and Collins, 2014; Baldi and Wallace Goodman, 2015).

In the UK, EU citizens' rights to free movement became a central focus of public and political debate following the EU enlargements. The UK government, initially at least, embraced the core principle of free movement by opening up its labour markets (Favell, 2014). Simultaneously, the UK introduced the Worker Registration Scheme (for A8 nationals) and the Accession Worker Card (for A2 nationals), which restricted rights to UK social welfare provisions; a move which was legal under the EU's transitional arrangements even though arguably it runs counter to the principle of non-discrimination set out in Article 18 TFEU. ${ }^{7}$

Following significant numbers of EU migrants entering the UK post A8 enlargement, the UK government introduced the Social Security (Persons from Abroad) Amendment Regulations 2006 SI 2006/1026, which specified that inactive persons would not be able to claim benefits if their right to reside was based solely on Directive 2004/38/EC. The European Commission subsequently began proceedings against the UK government arguing that these new requirements contradicted the non-discrimination principle that underpins EU law. Nonetheless, since 2014 the UK government has instigated significant policy changes to further curtail the rights of EU migrants to social assistance (see Table 1); changes deemed necessary to deter benefit tourism, reduce expenditure and retain the integrity of the UK benefit system (Kennedy, 2014).

Table 1: Changes to EU nationals' rights to social benefits in the UK

\begin{tabular}{|l|l|}
\hline Date & Change in UK policy \\
\hline January 2014 & $\begin{array}{l}\text { EU nationals claiming income based JSA will not be considered 'Habitually Resident' } \\
\text { unless they have been living in the Common Travel Area' for three months. } \\
\text { From the outset of their claim, EU nationals will need to offer evidence that they are } \\
\text { 'seeking employment' and have a 'genuine chance of being engaged' to be eligible } \\
\text { for income-based JSA. Continued receipt of JSA will only continue after six months if } \\
\text { they can provide 'compelling evidence' that they are actively seeking work and have } \\
\text { a 'genuine prospect of work', under the Genuine Prospect of Work Test (GPoWT) }\end{array}$ \\
\hline March 2014 & $\begin{array}{l}\text { A new Minimum Earnings Threshold (initially set at } £ 153 \text { per week) was established. } \\
\text { This is to be used to determine whether an EU national is in 'genuine and effective } \\
\text { work' and therefore has a right to reside in the UK as a 'worker' or 'self-employed } \\
\text { person'. }\end{array}$ \\
\hline April 2014 & $\begin{array}{l}\text { EU nationals whose only right to reside is derived from their status as 'jobseeker' } \\
\text { are no longer able to access Housing Benefit. Existing EU national Housing Benefit } \\
\text { claimants can continue to receive it. EU 'workers' or 'self-employed persons' who } \\
\text { retain their worker status on stopping work - for example, due to incapacity - are } \\
\text { not affected. }\end{array}$ \\
\hline July 2014 & $\begin{array}{l}\text { New EU migrant jobseekers arriving in the UK need to live in the country for three } \\
\text { months in order to claim Child Benefit and Child Tax Credit. }\end{array}$ \\
\hline 2015 & $\begin{array}{l}\text { Under new regulations EU migrants have no right to claim Universal Credit (which } \\
\text { replaces six means tested benefits) in the UK. }\end{array}$ \\
\hline
\end{tabular}

Note: ${ }^{1}$ The Common Travel Area (CTA) comprises the UK, Ireland, Isle of Man and the Channel Islands.

Sources: HM Treasury, 2014; Kennedy, 2014; 2015; Sibley and Collins, 2014; O’Brien, 2015; 2016; Shutes, 2016 
The UK's restrictions on EU migrants' rights have been subject to much critical discussion. O'Brien (2015) raises four key objections. First, that they are incompatible with the principles underpinning the TFEU and EU law and many prior judgments of European Court of Justice (ECJ). Second, as residency rules and the 'Genuine Prospect of Work Test' (GPoWT) are to be universally applied to all EU migrants, that the UK's restrictions have a negative impact on the rights of all EU migrants, beyond those who are economically inactive. Third, that the reforms are based on a gendered (compare Sibley and Collins, 2014) and individualist ideology that is likely to disproportionately affect the most vulnerable EU migrants (for example, lone parents and disabled people) and promote child poverty and destitution. Fourth, O'Brien argues that 'the entrenched administrative xenoscepticism', which the new rules generate, is likely to promote intolerance and error among those who implement policy. The full consequences of the narrow victory for the Leave campaign are as yet unknown. What is clear, however, is that the current situation is one in which EU migrants' rights in the UK have been systematically undermined. Following a brief methods note, ensuing discussions consider how the UK governments' benefit restrictions have had an impact on EU migrants' lives.

\section{Methods}

Discussions below draw on new data generated in two rounds of repeat semistructured interviews conducted with 49 EU migrants between 2014 and 2016, as part of a large, qualitative, longitudinal panel study exploring the impacts of welfare conditionality across a diversity of welfare service users living in England and Scotland (see Dwyer and Bright, 2018). The 49 respondents featured are migrants, as defined by the United Nations (that is, 'a person who moves to a country other than that of his or her usual residence for a period of at least a year so that the country of destination effectively becomes their new country of usual residence' (UN, 2013)) and are citizens of 14 EU MS (that is, Czech Republic, Estonia, France, Germany, Greece, Latvia, Lithuania, Ireland, Netherlands, Poland, Portugal, Romania, Slovakia and Spain). ${ }^{8}$ All are adults with experience of applying for social welfare benefits in the UK. Respondents had been UK residents between one and 23 years at the time of their first interview; 26 are female and 23 male.

Two principles, informed consent and anonymity, underpinned the fieldwork. Before each interview, individuals were provided with an information sheet, given the opportunity to ask questions and made aware of their right to withdraw from the study at any time. Written consent forms were used to reiterate understandings of consent and anonymised code numbers were assigned to each interview, for example, BR-LS-012a. ${ }^{9}$ Interpreters and translated materials were made available as required. Interviews were conducted in places convenient for respondents including cafés, community/support agency offices and migrants' homes. Participants received a $£ 20$ shopping voucher after each interview as a thank you for their time.

Interviews were audio recorded and verbatim English language transcripts produced. Two approaches informed data analysis. In order to enable temporal analysis across the wider sample, a common coding schema was developed for application across all sampled groups and data was summarised using a framework matrix approach (Lewis, 2007) and QSR NVivo software. Additionally, 'bottom up' thematic analysis (Mason, 2002) of each migrant transcript was undertaken. 


\section{Rescinding rights: the impacts of UK residency rules and the 'genuine prospect of work test'}

The UK's enhanced residency tests for EU nationals had clear detrimental impacts on respondents' lives. Thirteen migrants spoke of being refused various benefits because they did not meet the new residency rules.

They told me I'm not eligible for Housing Benefit because I'm coming from [Nation]...I used to claim Housing Benefit and then I moved...I did a new claim and they said, 'Oh no, you don't have rights to claim Housing Benefit because...you're not UK citizen'. (LO-KJ-004)

Similarly, a lone parent whose right to reside derived solely from their status as a 'jobseeker', confirmed at her second interview that she had been refused support.

I am no longer eligible for Housing Benefit... because of my nationality and that means that the next thing they're going to kick us out because who is going to pay for my rent? (BR-JM-022)

Refused Housing Benefit, another EU migrant was living in an illegally parked caravan. After being moved on by the police, he too was fearful of impending homelessness, and had struggled to convince the local JC+ that he was 'lawfully resident' and had a right to claim Jobseeker's Allowance (JSA). Ultimately, he succeeded, but only after providing detailed proof of residence and intermittent self-employment.

They've changed the rules. You have to be lawfully resident here. I don't know what lawfully means exactly...they asked me for proof from the doctor, from my son's school and for bank statements... It was very difficult. They also wanted to know what work I did, what we lived on, then eventually I got a letter from the [Company] to prove that I had worked. (BR-JM-009)

Other migrants fared worse. One man who had previously worked continuously for seven years in the UK, became homeless after losing his job and experiencing serious mental illness. When first interviewed he had been rough sleeping for nine months, was physically and mentally unwell, and entirely reliant on homelessness charities for food. Because of his situation, he was unable to provide the required documentation to prove his past record of residency and paid employment in the UK. JC+ refused his benefit claim, which subsequently left him unable to access hostel accommodation.

It has smashed my life like this. I am exhausted. I don't know what I can do or where I can go...The Jobcentre said they didn't have any more information... She knew all the information about who I am and how many years I've been working in this country. I have lots of photocopies of these documents... it's not easy for me because the Jobcentre hasn't accepted who I am...the Jobcentre says No, No. (BR-PD-001)

At our second interview twelve months later, he explained that with the help of a homelessness support worker, he had taken his case to a tribunal where the adjudicator, 
'within five minutes', upheld his right to social assistance and expressed surprise that he had been denied benefit. Able to claim Housing Benefit and Employment and Support Allowance (ESA), the reinstatement of his right to social assistance enabled him to move into supported accommodation, begin addressing his health issues and engage in voluntary work.

Many EU migrants, and it would appear JC+ staff, were confused about how complex residency rules affected individual migrant's rights to specific benefits. This confusion had serious consequences with poor advice from JC+ staff leading to applications for ineligible benefits. One woman resident in the UK for over a decade, failed to satisfy habitual residence rules because of an overseas internship undertaken while in UK higher education. Further complications followed when, after a period of illness during pregnancy,

One of the advisers advised me wrongly to get ESA...I'm still in arrears with my landlord because of all this... They advised me to go on Income Support [but] I would not pass the habitual residency status due to my leave for my internship... That wasn't quite fair. To even say that and let me go for something that I would not get due to the fact that they have not been trained enough...that affected me badly, my landlord gave me the eviction notice... They didn't reinstate my Jobseeker's... They didn't class me as a rapid reclaim... They still classed me as [if]I came to the UK three months on the new benefit cap basis. (PE-LS-010)

Ineligible for benefits this lone mother could not pay her rent and faced impending eviction, despite that all her adult life she had lived, studied and worked in the UK. 'I came to England when I was 18; all my work was based in England' (PE-LS-010).

Residency status and its importance for maintaining access to social assistance benefits was a recurrent problem. However, the majority of EU migrants, having routinely entered the UK as workers, only became aware of its significance, if and when, unemployment triggered a need to claim a social assistance benefit.

EU nationals, can be living here for years and do not have the right to reside, or they lose it. So yes, in order to keep it you need to sign on...most people have no idea about it. I didn't know about it. I didn't want to sign on initially, because I had some savings. I just wanted Housing Benefit, because I was looking for work and I was confident I was going to find employment soon. But the council said we cannot pay you any Housing Benefit unless you're claiming JSA. Eventually I found out that, yes, you keep your residency status when you are on one of these benefits. (LO-LS-004)

\section{A 'genuine prospect of work'}

Introduced in 2014 the 'Genuine Prospect of Work' test (GPoWT) applies only to EU migrants. It requires individuals to provide 'compelling evidence' that they are actively seeking work and have a 'genuine prospect of work', to retain eligibility for JSA. Neither term is tightly defined and Department for Work and Pensions Decision Makers draw on illustrative vignette case studies set out in a guidance memo in reaching eligibility decisions (DWP, 2015). In reality to successfully pass the 
GPoWT, EU migrants must have either a written job offer with a start date within three months which pays above the 'Minimum Earnings Threshold', or they must provide compelling proof that following a job interview in the past two months an offer of such work is imminent (O'Brien, 2016).

Meeting the requirements of GPoWT proved to be an additional unsurmountable barrier for many migrants, even those who had long histories of residence and paid employment in the UK. One man with an established UK based employment record reported consistently meeting his mandatory work search requirements before abruptly being informed that he was no longer entitled to JSA, unless he could produce a letter from a prospective employer.

I'd gone to this Jobcentre three or four weeks just for signing and then...I was told I'm not entitled because of the new regulations [GPoWT]. I have this book where I write how I'm looking for a job...It's not enough for them because they need the proof that in the future I will get a job in the form of a letter for your potential employer...It's the way to nowhere, so in the sense nobody could obtain these benefits, because I couldn't find an employer who'll guarantee you a job in three/four months' time...I couldn't prove that I will be employed in the future. (LO-KJ-003)

Like many EU migrants, this man had undertaken long periods of agency work and self-employment within the UK. Following the 2008 financial crisis work dried up, he became depressed and his life 'went to the dogs'. Unable to satisfy the GPoWT he could not access benefits to pay for accommodation and, like several other respondents, became homeless and was sleeping on the floor of a disabled man's bed and breakfast accommodation in return for acting as his unofficial personal carer. Another woman, a long-term UK resident with a past history of paid work, made two unsuccessful claims for JSA and also had an appeal refused.

Because I'd been in this country for 12 years I thought I am actually entitled, I am an EU citizen who is a permanent resident of the UK...I tried to get those people to acknowledge that...Genuine Prospect of Work, these people said, 'No, we don't believe you have it'...their final decision. (LO-PD-003)

At her second interview, this woman reported that she had briefly been able to access JSA prior to starting new employment. This only became possible when she was able to provide a job offer letter as the required 'compelling evidence' of a 'genuine prospect of work'. Previously she experienced a lengthy period without financial support that resulted in rent arrears.

Because I had a job offer, I could show them that this is a genuine prospect of work...So they paid me JSA for a brief period of time from my job offer to my starting date... How was I surviving during that time [when previously refused JSA because of the GPoWT]? I was not paying my rent. (LO- PD-003)

She resented that, as a legally resident EU migrant who had demonstrated the capacity over several years to find work and contribute through the taxation system to UK 
economy she was, nonetheless, denied entitlement to JSA until she met GPoWT criteria.

Another woman, who had left her partner due to serious domestic violence, also detailed the impact of failing the GPoWT. At our first interview although perturbed by the curtailment of EU nationals' rights, she was nonetheless, relatively, and wrongly, optimistic that as an existing JSA claimant, she would be immune from the effects of the GPoWT. However, at our second interview she had subsequently failed the criteria with damaging consequences.

On the date of my [GPoWT] interview I had no job offers... On the basis of that alone...they stopped my benefit and that had enormous, catastrophic results in my life...it had a domino effect... once my Jobseeker's was gone the next thing I know my Housing Benefit was stopped...I had an eviction notice from the safe house, and the social worker came to the house and he was not in any mood, it looked like, that he was willing to help. For whatever reason, even though we are protected, I mean universally protected by human rights aren't we? However, on the one and only occasion of his home visit, he was willing to pass the case onto his supervisor, his manager, and ask that they pay for our air ticket, for me and [CHILD] to go to [COUNTRY OF ORIGIN]. (BR-JM-22)

Assisted by a support worker she engaged an immigration lawyer but the mandatory reconsideration of the decision was rejected. She later managed to find agency work; however, her housing status remained precarious and she was fighting a second eviction notice for rent arrears, accrued when she was unable to work due to a zero hours employment contract.

The UK's restrictive residency rules and the GPoWT are clearly being implemented to deny EU migrants, including many with established employment histories who have previously contributed through the taxation and national insurance system to the UK economy, access to basic social assistance benefits. This has seriously detrimental effects on their ability to meet their basic needs and promotes homelessness and near destitution for some. Additionally, the recent EU migrant specific restrictions are being applied against the backdrop of a UK welfare state that is characterised by intensified and extended individual behavioural conditionality rather than collectivised rights to social security (Dwyer, 2016).

\section{EU migrants' everyday encounters of sanction and support in the UK's conditional welfare state}

A principle of welfare conditionality holds that certain basic, publicly provided, welfare benefits and services should 'be subject to the condition that those who receive them behave in particular ways, or participate in specified activities' (Deacon, 1994, 53); most notably the duty to undertake paid work. Those outside the PLM who cannot, or who will not, actively seek work are subject to sanctions, that is, reduction or removal of right to benefit or support. Both UK citizens and EU migrants alike who are not in paid work are now required to engage in compulsory work-focused interviews (WFIs), work search or work preparation/training activities as specified by $\mathrm{JC}+$ or Work Programme ${ }^{10}$ advisors or face sanctions ranging from four weeks 
benefit loss for a minor offence (for example, being late for a JC+ appointment) to up to three years' disqualification for a third, repeat high level offence, such as refusing to take up a job offer (DWP, 2012). In common with other non-migrant respondents in the wider study, benefit sanctions were often seen as inappropriately applied for relatively minor misdemeanours. Their effects were universally reported as negative, with sanctions regularly triggering severe financial and emotional hardship.

However, EU migrants face additional problems in their dealings with UK benefits system. These stem from two factors, a lack of English language proficiency among some EU migrants, and ill-informed and/or hostile face-to-face encounters with administrative staff who implement policy. In 2014 routine access to interpreters for new JSA claimants ended, with interpretation or translation services now available at the discretion of JC + advisers. This caused problems for respondents with limited English, who struggled to understand the requirements placed on them and any resultant sanctions for non-compliance. Moreover, benefit conditionality and language issues further interact under rules that allow JC+ staff to require JSA claimants with limited spoken English to undertake language training to enhance employment opportunities. Benefit sanctions can be applied for refusal to engage with the training or not making enough effort to improve English proficiency within a six-month period (HMT and DWP, 2014).

As earlier discussions illustrate, EU law and UK immigration and welfare legislation combine to create a complex system of differential and diminished access to welfare benefits for EU migrants. At the level of implementation this creates myriad misunderstandings about individual migrant's rights among administrators. EU migrants regularly spoke of confused and contradictory meetings with JC+ staff who were ill advised or commonly misinterpreted benefit entitlements.

The people in the Jobcentre they don't know the legislation, they have no idea what the law says regarding especially migrants. (LO-PD-003)

I have many letters and every letter is different... a letter that says everything is all right and then...it's not all right because someone missed something. (BR-PD-001)

EU migrants clearly resented the more onerous requirements (for example, the GPoWT) they had to meet, compared to UK non-migrant citizens, in order to access social assistance benefits. Many complained of institutionalised discrimination, 'In this country we are supposed to have the same rights, but they deal with us in a different way, we have fewer rights' (GL-SJ-001a), with a small number believing that the negative treatment they received, because of their nationality, ethnicity or 'migrant' status emanated from individual staff's racist attitudes.

They phoned somebody higher, just had a laugh and just said back, 'They're not allowed, just tell them they are not allowed to have that benefit because they are foreigners.' (PE-LS-012)

While complaints of racist attitudes and ethnic discrimination were relatively rare among respondents, existing evidence highlights the significance of discriminatory and racialised attitudes in influencing the sanctioning and support decisions of welfare 
administrators in the USA (Monnat, 2010). A UK report considering JC+ provision also notes a perceived punitive approach to the application of benefit sanctions among some young JSA claimants from Black and Minority Ethnic communities (Hudson et al, 2006); a finding which echoes the wider racism characteristic of much UK welfare policy and practice (Craig, 2007).

\section{Conclusions: diminished citizenship}

Through analysis of the new data generated in qualitative interviews, this paper makes an original and grounded contribution to understanding the significance and impacts of conditionality, operating at different levels, in restructuring and restricting the social rights and responsibilities of EU migrants resident in the UK. The more expansive vision of EU citizenship previously endorsed in the judgments of the ECJ has morphed into a reality in which 'increasingly EU migrants are being tolerated as residents with precarious status without access to minimum subsistence benefits' (Heindlmaier and Blauberger, 2017, 1). This reflects a wider shift whereby the social goals of the EU have become subordinate to 'necessary economic objectives' (Bruff, 2017) with the progressive equality fundamental to the European Social Model abandoned (O'Brien, 2013b)). Regardless, with Brexit forthcoming, recourse to EU law in defence of EU migrants' rights will likely soon be redundant. At the UK level, conditionality retains enhanced significance for EU migrants in two linked ways. First, in the broad sense related to how, since 2014, immigration and welfare policies have come together to restrict and rescind EU migrants' rights to residency and social assistance. Second, and more narrowly, in respect of how EU migrants experience the implementation of behavioural conditionality, in their everyday interactions with the JC+ and WP staff who administer the sanctions and conditional support that are now an integral part of the UK's 'work first' welfare state. Furthermore, in a period of fiscal crisis and welfare retrenchment, Euroscepticism and concerns about the negative impacts of increased migration in general (and post Accession EU migration in particular), have exercised the minds of certain British politicians and a significant proportion of the general public (Hoggett et al, 2013). Such negative views, fuelled by the xenophobia of some UK citizens have been influential in creating an environment which allows UK governments to demand that EU migrants must meet the additional, onerous, requirements of the GPoWT, over and above the conditions that UK citizens are subject to. Against the wider context of the UK's referendum on EU membership and the subsequent vote for Brexit, a unique constellation of conditionality has emerged to bring about a diminished version of social citizenship for EU migrants in the UK. As evidence presented in this paper shows, this is likely to further limit EU migrants' access to social protection, even for those with long records of previous paid employment in the UK. Consequently, many who have made a sustained contribution through paid work find that they are unable to claim a right to social assistance in times of need. With formal Brexit negotiations ongoing, the rights of EU migrants in the UK remain uncertain. Despite a stated desire 'to guarantee the rights of EU citizens who are already living in Britain' (May, 2017), the UK government has declined to issue further assurances until the rights of UK citizens living elsewhere in Europe are established. Irrespective of the outcome of negotiations it is improbable that EU migrants' rights will be enhanced in the future, more likely migrants from the EU entering the UK after Brexit may find that they 
are subject to the strict 'no recourse to public funds' rules currently applied to those migrants who enter from beyond the borders of Europe.

\section{Funding acknowledgement}

The support of the Economic and Social Research Council under grant reference number ES/K002163/2 is gratefully acknowledged.

\section{Notes}

${ }^{1}$ A8 states are: Poland, Lithuania, Estonia, Latvia, Slovenia, Slovakia, Hungary and the Czech Republic.

${ }^{2}$ Bulgaria and Romania.

${ }^{3}$ Throughout we routinely use the term EU migrants rather than EEA migrants for clarity. The EEA countries are Austria, Belgium, Bulgaria, Croatia, Cyprus, Czech Republic, Denmark, Estonia, Finland, France, Germany, Greece, Hungary, Iceland, Ireland, Italy, Latvia, Liechtenstein, Lithuania, Luxembourg, Malta, Netherlands, Norway, Poland, Portugal, Romania, Slovakia, Slovenia, Spain and Sweden.

${ }^{4}$ For discussions of the negative implications for women of attaching rights to an individual's status as a European worker rather than a citizen see, for example, O'Brien (2013b).

${ }^{5}$ Income Support, income-based JSA, income-related ESA, Pension Credit, Housing Benefit, Council Tax reduction, Child Benefit, Child Tax Credit and housing assistance from local authorities.

${ }^{6}$ See O'Brien (2016) and Heindlmaier and Blauberger (2017) for details.

${ }^{7}$ Article 18 TFEU states that 'Within the scope of application of the Treaties, and without prejudice to any special provisions contained therein, any discrimination on grounds of nationality shall be prohibited.'

${ }^{8}$ To protect anonymity respondent nationality is not specified.

${ }^{9}$ This identifies the location of the interview BR (that is, Bristol) and interviewer.

${ }^{10}$ In 2011 the Work Programme (WP) replaced New Labour's flexible New Deals and Welfare to Work schemes. The WP offers back to work and job sustainment support for the longer-term recipients of JSA, ESA and UC. Delivered by a range of private and third sector organisations, under a so-called 'black box' approach, providers are given a large degree of discretion in the mix of personalised sanction and support that they can use with individuals to help them (re)connect with the paid labour market. Failure to engage with specified requirements leaves clients liable to benefit sanctions (see Finn, 2013).

\section{References}

Ackers, L, Dwyer, P, 2002, Senior citizenship? Retirement, mobility and welfare in the European Union, Bristol: Policy Press

Baldi, G, Wallace Goodman, S, 2015, 'Migrants into members: social rights, civic requirements, and citizenship in Western Europe', West European Politics, 38, 6, 1152-1173.

Blair, T, 2004, Speech by Tony Blair to the Confederation of British Industry on migration, www.theguardian.com/politics/2004/apr/27/immigrationpolicy.speeches

Breidahl, KN, 2012, 'Immigrant-targeted activation policies: a comparison of the approaches of Scandinavian welfare states', in M Kilkey, G Ramia, K Farnsworth (eds) Social Policy Review 24, Bristol: Policy Press/Social Policy Association 
Bruff, I, 2017, Cease to exist? The European 'Social' Model and the hardening of soft EU law, in C Burak Tansel (ed) States of Discipline: Authoritarian Neoliberalism and the Contested Reproduction of Capitalist Order, London: Rowman and Littlefield International

Bruzelius, C, Chase, E, Seeleib-Kaiser, M, 2016, Social rights of EU migrant citizens: Britain and Germany compared, Social Policy and Society, 15, 3, 403-416

Carmel, E, Cerami, A, 2011, Governing migration and welfare: Institutions and emotions in the production of differential integration, in E Carmel,A Cerami, and $\mathrm{T}$ Papadopoulos (eds) Migration and Welfare in the new Europe: Social protection and the challenges of integration, Bristol: Policy Press, pp 1-22

Case C-67/14, Jobcenter Berlin Neukö I lnv Nazifa Alimanovic and Others, EU:C:2015:597

Case C-85/96, María Martínez Sala v Freistaat Bayern, EU:C:1998:217

Case C-299/14, Vestische Arbeit Jobcenter Kreis Recklinghausen v Jovanna García-Nieto and Others, EU:C:2016:114

Clasen, J, Clegg, D, 2007, Levels and levers of conditionality: Measuring change within welfare states, in J Clasen and NA Seigel (eds) Investigating Welfare State Change:The 'Dependent Variable Problem' in Comparative Analysis, Cheltenham: Edward Elgar, pp 166-197

Cook, J, Dwyer, P, Waite, L, 2012, 'Accession 8 migration and the proactive and defensive engagement of social citizenship', Journal of Social Policy 41, 2, 329-347

Craig, G, 2007, 'Cunning, unprincipled, loathsome': The racist tail wags the welfare dog', Journal of Social Policy,36, 4, 605-623

Currie, S, 2008, Migration, Work and Citizenship in the Enlarged European Union, Farnham: Ashgate

Deacon,A, 1994,Justifying workfare:The historical context of the workfare debates, in M White (ed) Unemployment and Public Policy in a Changing Labour Market, London: Policy Studies Institute

DWP (Department for Work and Pensions), 2012, Changes to Jobseeker's Allowance Sanctions from 22 October 2012, London:Department for Work and Pensions: http:// webarchive.nationalarchives.gov.uk/20130627060116/http:/www.dwp.gov.uk/ adviser/updates/jsa-sanction-changes/

DWP (Department for Work and Pensions), 2015, Decision Makers' Guide: Volume 2 Amendment 31 - June 2015 Habitual Residence and Right to Reside - IS/JSA/SPC/ ESA, London: Department for Work and Pensions, www.gov.uk/government/ uploads/system/uploads/attachment_data/file/446058/v2am31.pdf

Dwyer, P, 2016, Citizenship, conduct and conditionality: Sanction and support in the 21st century UK welfare state' in Social Policy Review 28, Bristol: Policy Press/ Social Policy Association, pp 41-62

Dwyer, P, Bright, J, 2018 Welfare conditionality: Sanctions support and behaviour change, Final Findings Report, York, University of York

Farage, N, 2014, Speech to UKIP's Spring conference, Guardian, www.theguardian. com/politics/2014/feb/28/nigel-farage-ukip-immigration-speech

Favell, A, 2014, The fourth freedom: Theories of migration and mobilities in 'neoliberal' Europe, European Journal of Social Theory 17, 3, 275-289

Finn, D, 2013, The design and delivery of 'payment-by-results' and 'black box' contracts: The case of the UK Work Programme, Paper to ICJS Research Seminar Series, 27 November, www.port.ac.uk/media/contacts-and-departments/icjs/downloads/ Finn-Full-PAPER-ICJS-seminar-Nov-2013.pdf 
Heindlmaier, A, Blauberger, M, 2017, Enter at your own risk: Free movement of EU citizens in practice, West European Politics, www.tandfonline.com/doi/full/10.108 0/01402382.2017.1294383

HMT (HM Treasury), DWP (Department for Work and Pensions), 2014, 'Further curbs to migrant access to benefits announced', News Story, 8 April, www.gov.uk/ government/news/further-curbs-to-migrant-access-tobenefits-announced

Hoggett, P, Wilkinson, H, Beedell, P, 2013, Fairness and the politics of resentment, Journal of Social Policy 42, 3, 567-585

Hudson, M, Barnes, H, Ray, K, Phillips, J, 2006, Ethnic minority perceptions and experiences of Jobcentre Plus, Research Report No 349, London: Department for Work and Pensions

Kennedy, S, 2014, People from abroad: what benefits can they claim?, House of Commons Library Standard Note SN/SP/6847, London: House of Commons

Kennedy, S. (2015) Measures to limit migrants' access to benefits, House of Commons Briefing Paper Number 06889, 17 June 2015, London: House of Commons

Lewis, J, 2007, Analysing qualitative longitudinal research in evaluations, Social Policy and Society 6, 4, 545-546

Lipsky, M, 1980, Street Level Bureaucracy: Dilemmas of the Individual in Public Services, New York: Russell Sage Foundation

Mason, J, 2002, Qualitative Researching, London: Sage Publications

May, T. (2017) 'Plan for Britain. The government's negotiating objectives for exiting the EU': Prime Minister's speech, 17 January 2017, Full transcript available at: https:// www.gov.uk/government/speeches/the-governments-negotiating-objectives-forexiting-the-eu-pm-speech

Migration Observatory, 2016, Pulling power: Why are EU citizens migrating to the UK, Commentary, 13 April, Oxford: University of Oxford, The Migration Observatory, www.migrationobservatory.ox.ac.uk/resources/commentaries/ pulling-power-eu-citizens-migrating-uk/

Monnat, SM, 2010, The color of welfare sanctioning: Exploring the individual and contextual roles of race on TANF case closures and benefit reduction, The Sociological Quarterly 51, 678-707

Mulvey, G, 2011, Immigration under New Labour: Policy and effects, Journal of Ethnic and Migration Studies 37, 9, 1477-1493

O'Brien, C, 2013a, From safety nets and carrots to trampolines and sticks: National use of the EU as both menace and model to help neoliberalize welfare policy, in D Schiek (ed) The EU Economic and Social Model in the Global Crisis, Farnham: Ashgate, 93-114

O’Brien, C, 2013b, I trade, therefore I am: Legal personhood in the European Union, Common Market Law Review 50, 1643-1684

O'Brien, C, 2015, The pillory, the precipice and the slippery slope: The profound effect of the UK's legal reform programme targeting EU migrants, Journal of Social Welfare and Family Law 37, 1, 111-136

O'Brien, C, 2016, Civis capitalist sum: Class as the new guiding principle of EU free movement rights, Common Market Law Review 53, 937-978

Oldfield,A, 1990, Citizenship and Community, Civic Republicanism and the Modern World, London: Routledge

Oliver, C, 2013, Immigrants and access to public services, ESRC Evidence Briefing, Oxford: COMPAS 
Parker, O, 2017, Critical political economy, free movement and Brexit: Beyond the progressive's dilemma, The British Journal of Politics and International Relations 19, 3, 479-496

Parker, O, López Catalán, O, 2014, Free movement for whom, where, when? Roma EU citizens in France and Spain, International Political Sociology 8, 379-395

Pollard, D, Ross, M, 1994, European Community Law: Texts and Materials, London: Butterworths

Pollard, N, Latorre, M, Sriskandarajah, D, 2008, Floodgates or Turnstiles? Post EU Enlargement Migration Flows (to and from) the UK, London: Institute for Public Policy Research

Shutes, I, 2016, Work related conditionality and access to social benefits of national citizens, EU citizens and non EU citizens, Journal of Social Policy 45, 5, 691-707

Sibley, E, Collins, R, 2014, Benefits for EEA migrants, Journal of Poverty and Social Justice 22, 2, 165-171

Stenning, A, Champion, T, Conway, C, Coombes, M, Dawley, S, Dixon, L, Raybould, S, Richardson, R, 2006, Final Report: Assessing the Local and Regional Impacts of International Migration, London: Department for Communities and Local Government

Thym, D, 2015, The elusive limits of solidarity: Residence rights of and social benefits for economically inactive union citizens, Common Market Law Review 52, 17-50

United Nations (Statistics Division), 2013, Principles and Recommendations for Vital Statistics, System, Revision 3, http://unstats.un.org/unsd/demographic/sconcerns/ migration/migrmethods.htm\#B

Weiler, J, 1998, European citizenship, identity and differentity, in M La Torre (ed) European Citizenship an Institutional Challenge, The Hague: Kluwer Law International 